\title{
Dr William Cadogan (1711-1797) of Bristol and the management of infants
}

\author{
P M Dunn
}

Apart from the fact that he was born in 1711, possibly in Cowbridge near Cardiff, not a great deal is known about William Cadogan's early life. ${ }^{1}$ He studied medicine at Oriel College, Oxford between 1727-32 and then in Leyden when he obtained his MD in 1737. Nothing is known of his activities during the next decade until, in 1747, Farley's Bristol fournal describes him as 'an eminent professor of physic in this city'. He had married Frances Cochran, the daugher of a wealthy planter in Antigua, and in May 1747 their daughter was born, also named Frances. Cadogan's interest in the upbringing of young children was no doubt stirred by the advent of a baby in his own household and a year later he wrote An Essay upon Nursing and the Management of Children from their Birth to Three Years of $\mathrm{Age}^{2}$ at the request of the Governors of the Foundling Hospital, an institution that had been opened in London by Captain Thomas Coram in 1741. This short pamphlet of just 34 pages earned Cadogan wealth, honour, and a lasting name in the history of paediatrics. During the next 37 years it ran through 12 editions and its honest commonsense did much to correct the appalling ignorance that existed at that time in respect to infant care. ${ }^{3}$

'The art of physick has been much improved within this last century; by observing and following nature more closely, many useful discoveries have been made, which help us to account for things in a natural way, that before seemed mysterious and magical; and which have consequently made the practice of it more conformable to reason and good sense. This being the case, there is great room to fear, that those nurses who yet retain many of these traditional prejudices, are capitally mistaken in their management of children in general, and fancying that nature has left a great deal to their skill and contrivance, often do much harm where they intend to do good. . . . The truth of what I say, that the treatment of children in general is wrong, unreasonable, and unnatural ... let any one, who would be fully convinced of this matter, look over the Bills of Mortality; there he may observe that almost half the number of those who fill up that black list, die under five years of age ... Ought it not therefore to be the care of every nurse and every parent, not only to protect their nurselings from injury, but to be well assured that their own officious services be not the greatest the helpless

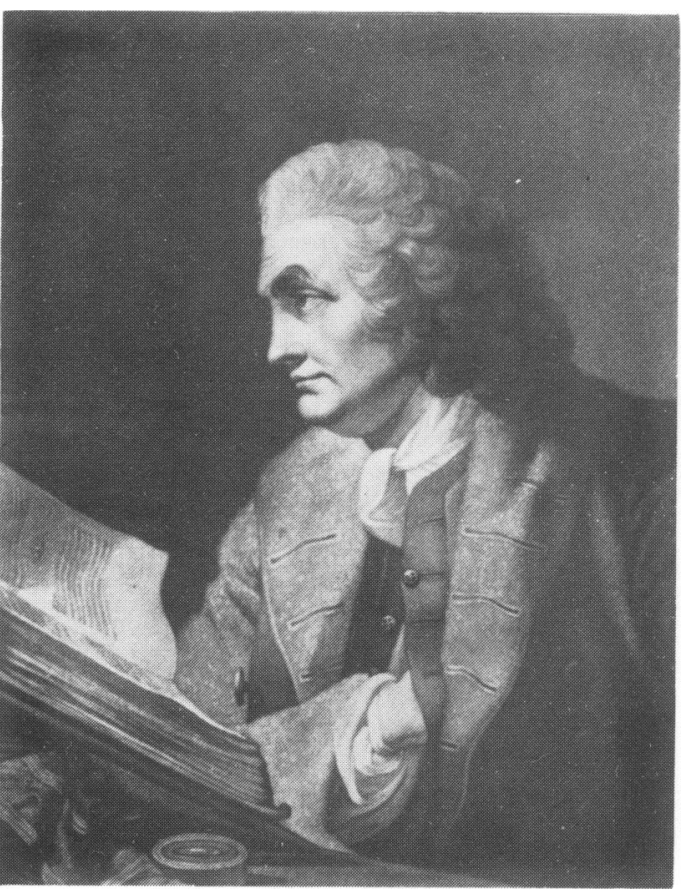

William Cadogan, 1711-1797.

creatures can suffer? . . . The mother who has only a few rags to cover her child loosely, and little more than her own breast to feed it, sees it healthy and strong, and very soon able to shift for itself; while the puny infant, the heir and hope of a rich family, lies languishing under a load of finery that overpowers his limbs, abhorring and rejecting the dainties he is crammed with, till he dies a victim to the mistaken care and tenderness of his fond mother ... children in general are overcloathed ... The truth is, a newborn child cannot well be too cool and loose in its dress; ... But, besides the mischief arising from the weight and heat of these swaddling-cloaths, they are put on so tight, and the child is so cramped by them, that its bowels have not room, nor the limbs any liberty, to act and exert themselves in the free easy manner they ought. This is a very hurtful circumstance; for limbs that are not used will never be strong, and such tender bodies cannot bear much pressure: the circulation restrained by the compression of any one part, must produce unnatural swellings in some other ...

The feeding of children properly is of much 
greater importance to them than their cloathing ... if we follow nature, instead of leading or driving it, we cannot err ... Her design is broke in upon, and a difficulty raised that is wholly owing to mistaken management. The child, as soon as it is born, is taken from the mother, and not suffered to suck till the milk comes of itself; but is either fed with strange and improper things, or put to suck some other woman . . . were the child kept without food of any kind (for six or seven hours), till it was hungry, which it is impossible it should be just after the birth, and then applied to the mother's breasts; it would suck with strength enough, after a few repeated trials, to make the milk flow gradually, in due proportion to the child's unexercised faculty of swallowing, and the call of its stomach. Thus the child would not only provide for itself the best of nourishment, but, by opening a free passage for it, would take off the mother's load, as it increased, before it could oppress or hurt her; and therefore effectually prevent the fever; which is caused only by the painful distention of the lacteal vessels of the breasts, when the milk is injudiciously suffered to accumulate ... When a child sucks its own mother, which, with a very few exceptions, would be best for every child and every mother, nature has provided it with such wholesome and suitable nourishment; . . . If I could prevail, no child should ever be crammed with any unnatural mixture, till the provision of nature was ready for it; nor afterwards fed with any ungenial alien diet whatever, at least for the first three months: for it is not well able to digest and assimilate other aliments sooner. I have seen very healthy fine children, that never eat or drank any thing whatever but the mother's milk for the first ten or twelve months. Nature seems to direct this, by giving them no teeth till about that time . . . Thus far nature, if she be not interrupted, will do the whole business perfectly well; and there seems to be nothing left for a nurse to do, but to keep the child clean and sweet, and to tumble and toss it about a good deal, play with it, and keep it in good humour.

The plain natural plan I have laid down is never followed, because most mothers, of any condition, either cannot, or will not undertake the troublesome task of suckling their own children; which is troublesome only for want of proper method; were it rightly managed, there would be much pleasure in it, to every woman that can prevail upon herself to give up a little of the beauty of her breast to feed her offspring; though this is a mistaken notion, for the breasts are not spoiled by giving suck, but by growing fat. There would be no fear of offending the husband's ears with the noise of the squalling brat. The child, was it nursed in this way, would be always quiet, in good humour, ever playing, laughing, or sleeping. In my opinion, a man of sense cannot have a prettier rattle (for rattles he must have of one kind or other) than such a young child. I am quite at a loss to account for the general practice of sending such infants out of doors, to be suckled or drynursed by another woman, who has not so much understanding, nor can have so much affection for it as the parents; and how it comes to pass, that people of good sense and easy circumstances will not give themselves the pains to watch over the health and welfare of their children; but are so careless as to give them up to the common methods, without considering how near it is to an equal chance, that they are destroyed by them'.

In 1749 Cadogan was elected a governor of the Foundling Hospital and in $\mathbf{1 7 5 2}$ he resigned his post in Bristol and moved to London. He was 41 . His success was immediate. Elected FRS in 1752, he was made physician to the Foundling Hospital in 1754, obtained MDs from both Oxford and Cambridge in 1755 and became a Fellow of the Royal College of Physicians in 1758. He was Censor to the College on four occasions and gave the Harveian oration twice, in 1764 and 1792 . In 1761 he was appointed physician to the army and served with it in Portugal in the war with Spain for several months the next year until invalided home.

In 1771 Cadogan produced his second important work, A Dissertation on the Gout . . ., a disease which he blamed on indolence, intemperance and vexation, advocating for its treatment, activity, temperance and peace of mind. He did not spare his colleagues commenting on the 'precarious skill of prescribing doctors' and the 'ignorant but enterprizing and influential quacks'. The book brought a storm of abuse about his head to which he remained indifferent, confident in the soundness of his assertions. His wife Frances had died and in 1759 he remarried a Mrs Spencer and, when she died, a third wife, Miss Groen in 1772. But there were no further children. He died at the age of 86 in 1797 and was buried in Fulham churchyard.

1 Rendle-Short J. William Cadogan-eighteenth-century physician. Med Hist 1960;4:288-309.

2 Cadogan W. An essay upon nursing and the management of children from their birth to three years of age. (In a letter to one of the governors of the Foundling Hospital. Published by the affairs of the said hospital.) London: J Roberts, 1748 .

3 Rendle-Short J. Infant management in the 18th century with special reference to the work of William Cadogan. Bull Hist Med 1960;34:97-122
Mecial reference to the 